\section{Inheritance of Resistance to Pepper huasteco yellow vein virus in Capsicum annuum L.}

\author{
Jesús Enrique Retes-Manjarrez ${ }^{1}$ \\ Universidad Tecnológica de Culiacán, Carretera a Imala kilómetro 3.1, s/n. \\ C.P. 80014, Culiacán, Sinaloa, México
}

Sergio Hernández-Verdugo, Carlos Alfonso López-Orona,
and Raymundo Medina-López
Facultad de Agronomía, Universidad Autónoma de Sinaloa, Carretera
Culiacán-Eldorado km 17.5, Culiacán, Sinaloa, México. C. P. 80000

José Antonio Garzón-Tiznado

Facultad de Ciencias Químico Biológicas, Universidad Autónoma de Sinaloa, Av. de Las Américas y Blvd. Universitarios s $/ n$, Culiacán, Sinaloa, México. C. P. 80013

\section{Jesús Enrique Retes-Cázarez \\ FitoCiencia, Camino al río Colonia Culiacancito, s/n. C.P. 80300 , Culiacancito, Culiacán Sinaloa, México}

Additional index words. pepper breeding, PHYVV, single recessive gene

\begin{abstract}
Pepper huasteco yellow vein virus (PHYVV) is a major disease in pepper (Capsicum annuum) that causes quantitative and qualitative losses to the crop in Central America and part of North America. To date, no resistant cultivars are available, and breeding is hampered by the lack of knowledge of the inheritance of this trait. Sources of resistance to PHYVV have been identified in the wild peppers of Mexico. The objectives of this study were to determine the grade of dominance, to analyze the maternal influence, and to estimate the number of genes involved in this resistant trait to PHYVV in the resistant wild pepper accession UAS12. Three susceptible parent lines-'Anaheim' (Ana), 'Ancho Gigante' (AG), and 'Yolo Wonder' (YW) - were crossed with resistant UAS12 accession to develop $F_{1}$ (reciprocal), $F_{2}$, and $B_{1}$ progenies in three families. Plants from this study were inoculated with PHYVV through Bemisia tabaci, evaluated phenotypically, and the segregation of disease scores was studied. A single recessive gene was found to control resistance to PHYVV in the resistant UAS12 accession, although segregation patterns suggested that other minor genes could participate in the expression of this resistant trait. No proof was found for maternal inheritance of PHYVV resistance. The gene symbol $p h v$ is proposed for PHYVV resistance in UAS12 accession in pepper. These results provide useful information for the design of pepper breeding programs in the introgression of this trait into commercial pepper backgrounds.
\end{abstract}

Mexico is one of the main producers of peppers (Capsicum annuum L.) worldwide, with around 176,517 ha cultivated in 2016 , representing about $65.4 \%$ of the total area cultivated for peppers in the Americas (Food and Agriculture Organization of the United Nations, 2018). Sinaloa State is one of the main producers of peppers in Mexico, where production reached 14,084 ha in 2016 (Secretaría de Agricultura, Ganadería, Desarrollo Rural, Pesca y Alimentación, Servicio de Información Agroalimentaria y Pesquera, México, 2018). Therefore, any limitations to the production of this crop is of concern.

PHYVV is one of the main viruses affecting pepper (Capsicum spp.) plants and other

Received for publication 9 Nov. 2018. Accepted for publication $20 \mathrm{Feb} .2019$.

${ }^{1}$ Corresponding author. E-mail: retesmje@hotmail. com.
Solanaceae in Mexico (García-Nería and Rivera-Bustamante, 2011; Garzón-Tiznado et al., 2002). The virus is widely disseminated in Mexico, the southern United States, and Guatemala (Nakhla et al., 2005; TorresPacheco et al., 1996). Its bipartite genome is transmitted by Bemisia tabaci $\mathrm{G}$, which is widely distributed worldwide and vectors the most devastating Geminivirus diseases (Morales and Anderson, 2001, Varma and Malathi, 2003). The main symptoms of PHYVV in pepper plants are yellow veins, leaf distortion, yellow mosaic, curling leaves, stunted plants, and reduction in yield (GarzónTiznado et al., 1993).

In general, management of this Begomovirus has been based mainly on chemical control through the use of insecticides against vector insects. This method is partially effective, costly, and a biohazard (Borah and Dasgupta, 2012). An effective alternative, without bio-risk, and accepted for the integrated management of Begomovirus, is the development of resistant genotypes to this group of pathogens (Shankarappa et al., 2008). The first step in the development of resistant cultivars to disease is the screening of wild and/or domesticated genetic resources that are used later in genetic breeding programs of agricultural crops (Pickersgill, 1997). The second desirable step is to analyze the genetic base of the target trait to design the best breeding model for introgression of the desirable trait into the cultivated background. The third step is to carry out the plan (Retes-Manjarrez et al., 2017).

Pepper may be infected by several viruses. The most common families of viruses attacking commercial fields of peppers in Central and North America are the Geminiviridae, Potyviridae, and Bromoviridae (Abdalla et al., 1991; Hernández-Espinal et al., 2018; Morales and Anderson, 2001; Pappu et al., 2009). Resistant commercial cultivars are available in these markets for the most common Potyviruses [Potato virus Y (PVY), TEV, and PepMoV] and Bromoviruses [Cucumber mosaic virus (CMV)]; however, no commercial pepper cultivars are resistant to Geminiviruses (PHYVV and PepGMV) in these important pepper markets.

There are several reports of resistance sources to PHYVV in Capsicum. Trujillo-Aguirre and Díaz-Plaza (1995) and Anaya-López et al. (2003) found genetic resistance to PHYVV and PepGMV in wild populations of Capsicum chinense from Southeast Mexico, and Hernández-Verdugo et al. (2001) and Retes-Manjarrez et al. (2016) found genetic resistance to PHYVV in wild populations of Capsicum annuum from Northwest Mexico. Despite that these resistance sources are promising for genetic breeding programs of Capsicum, to date pepper cultivars resistant to PHYVV have not been described. This could be the result of a lack of studies of the genetic basis of the resistance trait to PHYVV.

Most of the resistance genes to viruses in peppers are inherited in a recessive manner. It is known that eight major resistance genes and several quantitative trait loci (QTLs) showing phenotypically distinct types of responses to potyvirus have been reported (Wang and Bosland, 2006). All of these eight genes ( $p v r 1, p v r 2, p v r 3, p v r 4, p v r 5$, pvr6, pvr7, and pvr8) are inherited in a recessive manner (Arnedo-Andres et al., 2004; Boiteux et al., 1996; Caranta et al., 1996, 1999; Dogimont et al., 1996; Grube et al., 2000; Kang et al., 2005; Kyle and Palloix, 1997; Pasko et al., 1996). On the other hand, Ayme et al. (2004) and Caranta et al. (1997) reported the combination of a major gene including QTLs effect in the resistance to PVY in the $C$. annuum accession 'Perennial'. In the Cucumovirus CMV, Singh and Thakur (1977) reported the presence of a recessive gene regulating resistance in the 'Perennial' accession as well. On the other hand, Yao et al. (2013), revealed that CMV resistance in accession 'BJ0747-1-3-1-1' of C. annuum is controlled by two partially additivedominant major genes and additive-dominant 
polygenes. These authors also identified two stable and major QTLs for CMV resistance.

For the Geminiviruses, García-Nería and Rivera-Bustamante (2011) reported that the resistant trait to PHYVV in one accession (BG-3821) of Capsicum chinense depends on two genes in a duplicate recessive epistatic relation. Another study of other Begomoviruses that attacked peppers in Asia revealed that the resistant trait to PepLCV in the accession Bhut Jolokia is regulated by one recessive gene (Rai et al., 2014). There has been no report of inheritance for resistance to PHYVV in C. annuum (UAS12). RetesManjarrez et al. (2016, 2017, 2018) suggested that PHYVV resistance in pepper accession UAS12 was not a simple monogenic inheritance because of the bimodal distribution of symptoms and the low heritability of this resistant trait observed during these studies. The elucidation of the gene interaction, maternal influence, and number of genes involved in this resistant trait to PHYVV in the UAS12 accession would support pepper breeders in designing the best genetic models for introgression of this resistant trait into commercial pepper backgrounds.

Based on previous studies with accession UAS12, we hypothesize that the inheritance of resistance to PHYVV follows more than one single gene mode of inheritance in a recessive manner. Therefore, the objectives of this study were 1) to determine the grade of dominance, 2) to analyze the maternal influence, and 3) to estimate the number of genes involved in this resistant trait to PHYVV in the resistant wild pepper accession UAS12.

\section{Materials and Methods}

Plant material. The parental lines used in this study were pepper cultivars Ana, AG, and YW that are highly susceptible to PHYVV, and the line UAS12 (generation 7 of selection) that is a wild pepper highly resistant to this virus according to Retes-Manjarrez et al. (2016, 2017, 2018). UAS12 accession was obtained from the Facultad de Agronomía at Universidad Autónoma de Sinaloa; Ana, AG, and YW were used as susceptible parents because they have high fruit yield and quality. All crosses were made using controlled handpollination in the greenhouse of the Facultad de Agronomía at Universidad Autónoma de Sinaloa in Sinaloa, Mexico. Three families were developed from three crosses: Ana $X$ $\mathrm{UAS} 12, \mathrm{AG} \times \mathrm{UAS} 12$, and $\mathrm{YW} \times \mathrm{UAS} 12$. The $F_{1}$ was self-pollinated and backcrossed to respective parental lines to obtain progenies $\mathrm{F}_{2}, \mathrm{BC}_{1} \mathrm{P}_{\mathrm{s}}$, and $\mathrm{BC}_{1} \mathrm{P}_{\mathrm{r}}$ for all three crosses. Each family contained seven progenies: $\mathrm{P}_{\mathrm{s}}, \mathrm{P}_{\mathrm{r}}, \mathrm{F}_{1}\left({ }_{+} \mathrm{P}_{\mathrm{s}} \times \precsim \mathrm{P}_{\mathrm{r}}\right), \mathrm{F}_{1}\left(+\mathrm{P}_{\mathrm{r}} \times \precsim \mathrm{P}_{\mathrm{s}}\right)$, $\mathrm{F}_{2}, \mathrm{BC}_{1} \mathrm{P}_{\mathrm{s}}$, and $\mathrm{BC}_{1} \mathrm{P}_{\mathrm{r}}$. For the cross between Ana $\times$ UAS 12, 547 plants were tested: $32 \mathrm{P}_{\mathrm{s}}$, $41 \mathrm{P}_{\mathrm{r}}, 46 \mathrm{~F}_{1}\left(\mathrm{OP}_{\mathrm{s}} \times{ }^{\top} \mathrm{P}_{\mathrm{r}}\right), 34 \mathrm{~F}_{1}\left(\mathrm{P}_{\mathrm{r}} \times{ }^{1} \mathrm{P}_{\mathrm{s}}\right)$, $344 \mathrm{~F}_{2}, 23 \mathrm{BC}_{1} \mathrm{P}_{\mathrm{s}}$, and $27 \mathrm{BC}_{1} \mathrm{P}_{\mathrm{r}}$. For the cross between $\mathrm{AG} \times \mathrm{UAS12}, 563$ plants were tested: $30 \mathrm{P}_{\mathrm{s}}, 40 \mathrm{P}_{\mathrm{r}}, 28 \mathrm{~F}_{1}\left({ }_{(} \mathrm{P}_{\mathrm{s}} \times{ }_{\partial} \mathrm{P}_{\mathrm{r}}\right), 35 \mathrm{~F}_{1}\left(\mathrm{P}_{\mathrm{r}} \times\right.$ $\left.{ }^{2} \mathrm{P}_{\mathrm{s}}\right), 378 \mathrm{~F}_{2}, 28 \mathrm{BC}_{1} \mathrm{P}_{\mathrm{s}}$, and $24 \mathrm{BC}_{1} \mathrm{P}_{\mathrm{r}}$. For the cross between $\mathrm{YW} \times \mathrm{UAS} 12,662$ plants were tested: $20 \mathrm{P}_{\mathrm{s}}, 41 \mathrm{P}_{\mathrm{r}}, 37 \mathrm{~F}_{1}\left(+\mathrm{P}_{\mathrm{s}} \times \lesssim \mathrm{P}_{\mathrm{r}}\right)$, $28 \mathrm{~F}_{1}\left(\mathrm{P}_{\mathrm{r}} \times{ }^{\top} \mathrm{P}_{\mathrm{s}}\right), 493 \mathrm{~F}_{2}, 22 \mathrm{BC}_{1} \mathrm{P}_{\mathrm{s}}$, and $21 \mathrm{BC}_{1} \mathrm{P}_{\mathrm{r}}$. These plants were used to test the inheritance from each cross.

Planting and management. The inheritance study was performed in the greenhouse of the Facultad de Agronomía at Universidad Autónoma de Sinaloa in Sinaloa, Mexico. Seeds were germinated in trays with 200 polystyrene wells in a germination chamber at $30 \pm 2{ }^{\circ} \mathrm{C}$. All experiments were performed with 50-d-old plants under greenhouse conditions with insect-proof netting and with temperatures varying between 22 and $38{ }^{\circ} \mathrm{C}$ for the duration of the study. We did specific treatments with Imidacloprid against whiteflies and pollinator insects (Confidor, Bayer Crop Sciences) every week in all trials.

Source of viral inoculum. The strain PHYVV "M53" was used, which was isolated from pepper plants Jalapeño-type cv. Grande from Seminis Vegetable Seeds (Woodland, CA) (Retes-Manjarrez et al., 2016). The inoculum-source plants were maintained in insect-proof wooden entomologic cages (length, $40 \mathrm{~cm}$; width, $40 \mathrm{~cm}$; height, $60 \mathrm{~cm}$ ) covered with organza fabric. Inoculating healthy Ana plants through grafting increased the number of inoculum-source plants.

Identification of the virus. For PHYVV identification, polymerase chain reaction (PCR) was used with primers $240 \mathrm{~F}$ and $241 \mathrm{R}$, which amplify a 350-bp fragment from the intergenic region of component A of the virus. The PCR conditions used for PHYVV detection were as described by Torres-Pacheco et al. (1996). DNA from the analyzed plants was extracted following the method of Dellaporta et al. (1983).

Source and maintenance of the vector insect. We used the insect source Bemisia tabaci biotype B free of the virus keep it from Retes-Manjarrez et al. (2016). The virus-free white flies were placed on cotton (Gossypium hirsutum L.) plants in wooden entomologic cages covered with organza fabric and kept in a nursery for 6 months at an average temperature of $28 \pm 2{ }^{\circ} \mathrm{C}$ to obtain a population free of virus that was large enough to be able to perform the PHYVV inoculation assays. According to Czosnek et al. (1993), Gossypium hirsutum is not a Begomovirus host that infects Solaceous crops. Cotton plants were substituted with young plants of this genera every 2 months. To corroborate the absence of other Begomoviruses in the whitefly colony, PCR was used with universal primers MotCP2118 (5'-CCGAATTCGACTGGACCTTACATGGNCCTTCAC-3') and MotCP2123 (5'-GAGTCTAGAGGSTANGTGAAGGAAATAA/ GTTCTTGGC-3') that amplify a 650-bp fragment from component $\mathrm{A}$ of the Begomoviruses (Ascencio-Ibáñez et al., 2002).

Resistance assay. The resistance assay was performed in Feb. 2017. After multiplication of whiteflies in the cotton plants, these insects were transferred to the inoculum source of PHYVV in pepper plants for $48 \mathrm{~h}$ as the virus acquisition period. Then, the insect inoculation method was used and consisted of placing a plastic bottle with 20 viruliferous adult-stage insects on individual plants of the different genotypes for a 48-h transmission period. After inoculation, an imidacloprid (Confidor 350 SC, Germany) treatment was applied to eliminate the insects. In total, we

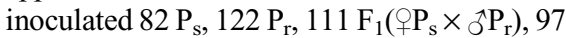
$\mathrm{F}_{1}\left(\mathrm{P}_{\mathrm{r}} \times{ }_{0} \mathrm{P}_{\mathrm{s}}\right), 1215 \mathrm{~F}_{2}, 73 \mathrm{BC}_{1} \mathrm{P}_{\mathrm{s}}$, and $72 \mathrm{BC}_{1}$ $\mathrm{P}_{\mathrm{r}}$ plants that were used to analyze the inheritance of the resistant trait in all the three families from each cross (Ana $\times$ UAS12, AG $\times$ UAS12, and $\mathrm{YW} \times$ UAS12) $50 \mathrm{~d}$ after sowing. A completely randomized design was used with one plant per replicate.

Evaluation of viral resistance. Resistance to PHYVV was assessed based on the level of symptoms. The level of resistance was evaluated using the scale of symptoms described by Retes-Manjarrez et al. (2016) at $60 \mathrm{~d}$ post infection, where 1 indicates the absence of symptoms and 9 corresponds to a plant with the most severe symptoms, which include dwarfing, curling, and distorted leaves with a clearly defined mosaic. After scoring, plants were tested using PCR to determine the presence of the virus in the leaf tissue. Leaf tissue used for testing was sampled from the top three leaves of the plant. Plants with a score of $\leq 4.0$ were chosen as resistant. All asymptomatic plants from both assays were analyzed for the presence of PHYVV viral DNA by PCR to discard escape plants.

Data analysis. The $\chi^{2}$ test for goodnessof-fit $(P<0.05)$ and homogeneity was used to examine segregation ratios (susceptible:resistant) for each $\mathrm{F}_{2}$ and $\mathrm{BC}_{1} \mathrm{P}_{\mathrm{r}}$ progeny with the SAS statistical package (ver. 8.00; SAS Institute, Cary, NC).

\section{Results}

All crosses among the three susceptible parents and the resistant parent produced uniformly susceptible $F_{1}$ progenies, indicating that PHYVV resistance is a recessive trait (Table 1). On the other hand, all reciprocal crosses among the three susceptible parents and the resistant parent also produced uniformly susceptible $F_{1}$ progenies, confirming that PHYVV resistance is a recessive trait with no maternal influence (Table 1). The $\mathrm{F}_{2}$, $\mathrm{BC}_{1} \mathrm{P}_{\mathrm{s}}$, and $\mathrm{BC}_{1} \mathrm{P}_{\mathrm{r}}$ progenies from all three crosses were tested to the expected ratios of a single gene inheritance. The $F_{2}$ segregation data obtained from the cross Ana $\times$ UAS12 and $A G \times U A S 12$ followed the expected ratio of 3 susceptible: 1 resistant, favoring the single gene inheritance hypothesis (Table 1). The cross $\mathrm{YW} \times \mathrm{UAS} 12$ was closed to follow the expected ratio of 3 susceptible: 1 resistant, but the $\chi^{2}$ test for goodness-of-fit $(P=0.09)$ analysis reject this single gene inheritance hypothesis (Table 1). All $\mathrm{BC}_{1} \mathrm{P}_{\mathrm{s}}$ progenies supported the expected ratio for a single recessive gene hypothesis, showing a 1 susceptible:0 resistant ratio (Table 1). The $\mathrm{BC}_{1} \mathrm{P}_{\mathrm{r}}$ populations of the families Ana $\times$ UAS12 and YW $\times$ UAS12 had a 1 susceptible: 1 resistant ratio, which also supported a single recessive gene mode of inheritance controlling resistance to PHYVV in UAS12 (Table 1). The $\mathrm{BC}_{1} \mathrm{P}_{\mathrm{r}}$ population of the family $\mathrm{AG} \times \mathrm{UAS} 12$ 
followed closely the expected ratio for a single recessive gene hypothesis, showing a 1 susceptible: 1 resistant ratio, but the $\chi^{2}$ test for goodness-of-fit $(P=0.23)$ analysis rejected this single gene inheritance hypothesis (Table 1). The pooled $F_{2}$ individuals segregated 885 susceptible:330 resistant with a $\chi^{2}$ value of $2.97(\mathrm{df}=1)$, showing that the data were not consistent with a 3:1 ratio (Table 2). The $P$ value for that $\chi^{2}$ did not confirm also a good fit of the data to the predicted values $(P$ value $=0.08)$. The homogeneity $\chi^{2}$ (with $\mathrm{df}=$ 2) for the $F_{2}$ was 0.29 , indicating that all crosses did not represent the same progeny and were not homogenous (Table 2). All asymptomatic plants $(\mathrm{n}=109)$ analyzed for the presence of PHYVV DNA by PCR from this study were positive for this virus and were considered resistant. This result discards escape plants.

\section{Discussion}

PHYVV has a serious impact on pepper production in Mexico, the southern United States, and Guatemala. Most of the time, PHYVV outbreaks result in losses through a reduction in growth, yield, and fruit quality. This virus infects several dicotyledonous plants, including pepper (Capsicum spp.), tomato (Solanum lycopersicum L.), tobacco (Nicotiana spp.), husk tomato (Physalis spp.), Solanum rostratum D., Cucurbita spp., Helianthus annuus L., Datura spp., Carica papaya L., Sorghum halepense P., and Melia azedarach L. (Garzón-Tiznado et al., 2002). The virus can be transmitted in a persistent, circulative manner by Bemisia tabaci, and not by mechanical inoculation and via seeds (Medina-Ramos et al., 2008). In the field, PHYVV outbreaks are quite difficult to control, leaving breeding for disease resistance as the most suitable method to control PHYVV epidemics. Hence, the use of commercial cultivars with high resistance to PHYVV would stabilize yield and improve fruit quality in pepper production areas in Mexico, the United States, and Guatemala.

It is common for plant breeders to identify wild relatives that serve as a source of resistance (e.g., the UAS12 pepper accession), although the genetic basis for the resistance has not been determined previously on this promising genotype. As reported elsewhere, the UAS12 pepper accession showed high resistance to PHYVV (Retes-Manjarrez et al., 2016, 2017, 2018). However, it was not determined whether this accession carries

Table 1. Single-locus goodness-of-fit test $(P<0.05)$ for resistance to Pepper huasteco yellow vein virus in C. annuum.

\begin{tabular}{|c|c|c|c|c|c|c|c|}
\hline Family & Progeny & Susceptible & Resistant & Expected $^{\mathrm{z}}$ & $\chi^{2}$ & $\mathrm{df}$ & $P$ value \\
\hline$\overline{\text { Anaheim (susceptible) } \times}$ & $\mathrm{P}_{\mathrm{s}}$ & 32 & 0 & & & & \\
\hline \multirow[t]{6}{*}{ UAS12 (resistant) } & $\mathrm{P}_{\mathrm{r}}$ & 6 & 35 & & & & \\
\hline & $\mathrm{F}_{1}\left(\uparrow \mathrm{P}_{\mathrm{s}} \times \precsim \mathrm{P}_{\mathrm{r}}\right)$ & 46 & 0 & & & & \\
\hline & $\mathrm{F}_{1}\left(\mathrm{P}_{\mathrm{r}} \times \precsim \mathrm{P}_{\mathrm{s}}\right)$ & 34 & 0 & & & & \\
\hline & $\mathrm{F}_{2}\left(\propto \mathrm{P}_{\mathrm{s}} \times \precsim \mathrm{P}_{\mathrm{r}}\right)$ & 253 & 91 & $3: 1$ & 0.39 & 1 & 0.55 \\
\hline & $\mathrm{BC}_{1} \mathrm{P}_{\mathrm{s}}$ & 23 & 0 & & & & \\
\hline & $\mathrm{BC}_{1} \mathrm{P}_{\mathrm{r}}$ & 14 & 13 & $1: 1$ & 0.07 & 1 & 0.78 \\
\hline Ancho Gigante (susceptible) $\times$ & $\mathrm{P}_{\mathrm{s}}$ & 30 & 0 & & & & \\
\hline \multirow[t]{6}{*}{ UAS12 (resistant) } & $\mathrm{P}_{\mathrm{r}}$ & 6 & 34 & & & & \\
\hline & $\mathrm{F}_{1}\left({ }_{+} \mathrm{P}_{\mathrm{s}} \times \precsim \mathrm{P}_{\mathrm{r}}\right)$ & 28 & 0 & & & & \\
\hline & $\mathrm{F}_{1}\left(\uparrow \mathrm{P}_{\mathrm{r}} \times \precsim \mathrm{P}_{\mathrm{s}}\right)$ & 35 & 0 & & & & \\
\hline & 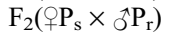 & 279 & 99 & $3: 1$ & 0.26 & 1 & 0.63 \\
\hline & $\mathrm{BC}_{1} \mathrm{P}_{\mathrm{s}}$ & 28 & 0 & & & & \\
\hline & $\mathrm{BC}_{1} \mathrm{P}_{\mathrm{r}}$ & 9 & 15 & $1: 1$ & 1.50 & 1 & 0.23 \\
\hline Yolo Wonder (susceptible) $\times$ & $\mathrm{P}_{\mathrm{s}}$ & 20 & 0 & & & & \\
\hline \multirow[t]{6}{*}{ UAS12 (resistant) } & $\mathrm{P}_{\mathrm{r}}$ & 6 & 35 & & & & \\
\hline & $\mathrm{F}_{1}\left(\ngtr \mathrm{P}_{\mathrm{s}} \times \precsim \mathrm{P}_{\mathrm{r}}\right)$ & 37 & 0 & & & & \\
\hline & $\mathrm{F}_{1}\left(\mathrm{P}_{\mathrm{r}} \times \precsim \mathrm{P}_{\mathrm{s}}\right)$ & 28 & 0 & & & & \\
\hline & $\mathrm{F}_{2}\left(\propto \mathrm{P}_{\mathrm{s}} \times \precsim \mathrm{P}_{\mathrm{r}}\right)$ & 353 & 140 & $3: 1$ & 3.13 & 1 & 0.09 \\
\hline & $\mathrm{BC}_{1} \mathrm{P}_{\mathrm{s}}$ & 22 & 0 & & & & \\
\hline & $\mathrm{BC}_{1} \mathrm{P}_{\mathrm{r}}$ & 11 & 10 & $1: 1$ & 0.19 & 1 & 0.68 \\
\hline
\end{tabular}

${ }^{\mathrm{z}_{\text {Expected }}}$ is the hypothesized segregation ratio for single-gene inheritance.

$\mathrm{P}_{\mathrm{s}}=$ susceptible parent; $\mathrm{P}_{\mathrm{r}}=$ resistant parent; $q=$ progenitor used as female; $\hat{\jmath}=$ progenitor used as male.

Table 2. Pooled and homogeneity data from the three crosses for resistance to Pepper huasteco yellow vein virus in C. annuum.

\begin{tabular}{|c|c|c|c|c|c|c|}
\hline Progeny & Susceptible & Resistant & Expected $^{\mathrm{z}}$ & $\chi^{2}$ & df & $P$ value \\
\hline \multicolumn{7}{|c|}{$\begin{array}{l}\text { Susceptible } \times \text { Resistant } \\
\text { crosses, pooled }\end{array}$} \\
\hline$P_{s}$ & 82 & 0 & & & & \\
\hline $\mathrm{P}_{\mathrm{r}}$ & 18 & 104 & & & & \\
\hline 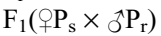 & 111 & 0 & & & & \\
\hline $\mathrm{F}_{1}\left(+\mathrm{P}_{\mathrm{r}} \times \precsim \mathrm{P}_{\mathrm{s}}\right)$ & 97 & 0 & & & & \\
\hline $\mathrm{F}_{2}\left(+\mathrm{P}_{\mathrm{s}} \times{ }^{\lambda} \mathrm{P}_{\mathrm{r}}\right)$ & 885 & 330 & $3: 1$ & 2.97 & 1 & 0.08 \\
\hline $\mathrm{BC}_{1} \mathrm{P}_{\mathrm{s}}$ & 73 & 0 & & & & \\
\hline $\mathrm{BC}_{1} \mathrm{P}_{\mathrm{r}}$ & 34 & 38 & $1: 1$ & 0.22 & 1 & 0.63 \\
\hline Homogeneity & & & & 0.29 & 2 & 0.58 \\
\hline
\end{tabular}

${ }^{\mathrm{z}}$ Expected is the hypothesized segregation ratio for single-gene inheritance.

$\mathrm{P}_{\mathrm{s}}=$ susceptible parent; $\mathrm{P}_{\mathrm{r}}=$ resistant parent; $q=$ progenitor used as female; $\hat{\jmath}=$ progenitor used as male. one or more genes controlling resistance to PHYVV. In our study, the UAS12 accession was tested for the inheritance of PHYVV resistance on segregating progenies from crosses with three susceptible cultivars. The inheritance data indicate that resistance to PHYVV, in all three crosses, was controlled by a single recessive gene. Similar results were also reported for inheritance of resistance to Begomovirus PepLCV on pepper Bhut Jolokia accession (Rai et al., 2014). On the other hand, our results differ from those reported by GarcíaNería and Rivera-Bustamante (2011), who reported that the resistant trait to PHYVV in the pepper accession of Capsicum chinense BG-3821 depends on two recessive genes with an epistatic relation. This difference from our results could mainly be the result of a different background of the genotypes that are different species. Our results from the inheritance study reject the hypothesis that PHYVV resistance in the UAS12 accession is controlled by more than one single gene and conclude that this resistant trait is controlled by at least one single recessive gene with minor effects from other genes. It has been found in pepper that other resistant traits to viruses are regulated by recessive genes with influence of QTLs. For instance, Ayme et al. (2004) and Caranta et al. (1997) revealed the combination of a major gene with QTLs effect in the resistance to PVY in one accession of $C$. annuum (Perennial). On the other hand, Yao et al. (2013) reported major genes with influence of some QTLs for the CMV-resistant trait in the accession 'BJ0747-1-3-1-1' of C. annuum. To the best of our knowledge, our study is the first to attempt to discern the inheritance of the resistance to PHYVV in Capsicum annuum genotypes. The UAS12 accession is a promising genotype for future pepper breeding programs in developing resistant cultivars. This accession has an added value because it is the unique source of resistance reported in Capsicum annuum, which is the most important globally of all cultivated species of Capsicum (van Zonneveld et al., 2015).

No influence of maternal inheritance was found. This result indicates that the UAS12 accession could be used in both senses (male or female) in the crossing blocks, although it is recommended to use it as a male because the emasculation of the flowers is complicated for its small size.

We propose naming this new gene Pepper huasteco yellow vein virus resistance, with the symbol $p h v$, in conformance with gene nomenclature rules for the Capsicum genus (CENL, Committee for Capsicum Gene Nomenclature, 1994).

\section{Literature Cited}

Abdalla, O.A., P.R. Desjardins, and J.A. Dodds 1991. Identification, disease incidence, and distribution of viruses infecting peppers in California. Plant Dis. 75:1019-1023.

Anaya-López, J.L., I. Torres-Pacheco, M. GonzálezChavira, J.A. Garzón-Tiznado, J.L. Pons-Hernández, R.G. Guevara-González, C.I. Muñoz-Sánchez, L. Guevara-Olvera, R.F. Rivera-Bustamante, and S. 
Hernández-Verdugo. 2003. Resistance to geminivirus mixed infections in Mexican wild peppers. HortScience 38:251-255.

Arnedo-Andres, M., M.L. Arteaga, and R.G. Ortega. 2004. New genes related to PVY resistance in C. annиum L. "Serrano Criollo de Morelos-334". Proc. 12 ${ }^{\text {th }}$ Eucarpia Meeting on Genetics and Breeding of Capsicum and Eggplant, Noordwijkerhout, the Netherlands, 17 19 May 2004.

Ascencio-Ibáñez, J.T., R.G. Arguello-Astorga, J. Méndez-Lozano, and R.F. Rivera-Bustamante. 2002. First report of Rhynchosia Golden mosaic virus (RhGMV) infecting tobacco in Chiapas, México. Plant Dis. 86:692.

Ayme, V., O. Pierrugus, S. Souche, G. Nemouchi, C. Caranta, M. Jacquemont, J. Chadoeuf, A. Palloix, and B. Moury. 2004. PVR evolution toward virulence to the resistance conferred by $p v r 2^{3}$ in pepper and consequences for its durability. Proc. $12^{\text {th }}$ Eucarpia Meeting on Genetics and Breeding of Capsicum and Eggplant, Noordwijkerhout, the Netherlands, 17-19 May 2004.

Boiteux, L.S., F.P. Cupertino, C. Silva, A.N. Dusi, D.C. Monte-Neshich, R.A.A. van der Vlugt, and M.E.N. Fonseca. 1996. Resistance to potato virus Y (pathotype 1-2) in Capsicum annuum and $C$. chinense is controlled by two independent major genes. Euphytica 87:53-58.

Borah, B.K. and I. Dasgupta. 2012. Begomovirus research in India: A critical appraisal and the way ahead. J. Biosci. (Rajshahi) 37:791-806.

Caranta, C., V. Lefebvre, and A. Palloix. 1997. Polygenic resistance of pepper to potyviruses consist of a combination of isolate-specific and broad-spectrum quantitative trait loci. Mol. Plant Microbe Interact. 10:872-878.

Caranta, C., A. Palloix, G. Gebre Selassie, V. Lefebvre, B. Moury, and A.M. Daubeze. 1996. A complementation between two genes originating from susceptible Capsicum annuит L. lines confers a new and complete resistance to pepper veinal mottle virus. Phytopathology 86:739-743.

Caranta, C., A. Thabuis, and A. Palloix. 1999. Development of CAPS marker for the Pvr4 locus: A tool for pyramiding potyvirus resistance genes in pepper. Genome 42:1111-1116.

CENL, Committee for Capsicum Gene Nomenclature. 1994. Rules for gene nomenclature of Capsicum. Capsicum Eggplant Nwsl. 13:13-14.

Czosnek, H., A. Kheyr-Pour, B. Gronenborn, E. Remetz, M. Zeidan, A. Altman, H.D. Rabinowitch, S. Vidavsky, N. Kedar, Y. Gafni, and D. Zamir. 1993. Replication of Tomato yellow leaf curl virus (TYLCV) DNA in agroinoculated leaf discs from selected tomato genotypes. Plant Mol. Biol. 22:995-1005.

Dellaporta, S.L., J. Woods, and J.B. Hicks. 1983. A plant minipreparation: Version II. Plant Mol. Biol. Rpt. 1:19-21.

Dogimont, C.A., A.M. Palloix, G. Daubeze, K. Marchoux, K.G. Selassie, and E. Pochard. 1996. Genetics of broad spectrum resistance to potyviruses in haplodiploid progenies of pepper (Capsicum annuum). Euphytica 88:231-239.

Food and Agriculture Organization of the United Nations. 2018. Statistics division. 6 Nov. 2018. $<$ http://faostat3.fao.org/>.
García-Nería, M.A. and R.F. Rivera-Bustamante. 2011. Characterization of geminivirus resistance in an accession of Capsicum chinense Jacq. Mol. Plant Microbe Interact. 24:172-182.

Garzón-Tiznado, J.A., G. Acosta-García, I. TorresPacheco, M. González-Chavira, R.F. RiveraBustamante, V. Maya-Hernández, and R.G. Guevara-González. 2002. Presencia de los Geminivirus, huasteco del chile (PHV), Texano del chile variante Tamaulipas (TPV-T) y Chino del tomate (VCDT), en los estados de Guanajuato, Jalisco y San Luis Potosí, México. Rev. Mex. Fitopatol. 20:45-52.

Garzón-Tiznado, J.A., I. Torres-Pacheco, J.T. AscencioIbañez, L. Herrera-Estrella, and R.F. RiveraBustamante. 1993. Inoculation of peppers with infection clones of a new geminivirus by biolistic procedure. Phytopathology 33:514-521.

Grube, R.C., J.R. Blauth, M. Arnedo-Andres, C. Caranta, and M.K. Jahn. 2000. Identification and comparative mapping of a dominant potyvirus resistance gene cluster in Capsicum. Theor. Appl. Genet. 101:852-859.

Hernández-Espinal, L.A., I. Enríquez-Verdugo, C.M. Melgoza-Villagómez, J.E. Retes-Manjarrez, S. Velarde-Félix, P.J. Linares-Flores, and J.A. Garzón-Tiznado. 2018. Phylogenetic analysis and distribution of begomovirus in pepper (Capsicum annum L.) crop in Sinaloa, Mexico. Rev. Fitotec. Mex. 41:149-157.

Hernández-Verdugo, S., R.G. Guevara-González, R.F. Rivera-Bustamante, and K. Oyama. 2001. Screening wild plants of Capsicum annuum for resistance to Pepper huasteco virus (PHV): Presence of viral DNA and differentiation among populations. Euphytica 122:31-36.

Kang, B.C., I. Yeam, J.D. Frantz, J.F. Murphy, and M.M. Jahn. 2005. The pvr1 locus in pepper encodes a translation initiation factor eIF4E that interacts with tobacco etch virus $\mathrm{VPg}$. Plant J. 42:392-405.

Kyle, M.M. and A. Palloix. 1997. Proposed revision of nomenclature for potyvirus resistance gene in Capsicum. Euphytica 97:183-188.

Medina-Ramos, G., R. De La Torre-Almaráz, R. Bujanos-Muñiz, R.G. Guevara-González, N. Tierranegra-García, L. Guevara-Olvera, M.M. González-Chavira, and I. Tórres-Pacheco. 2008. Co-transmission of Pepper huasteco yellow vein virus and Pepper Golden mosaic virus in chili pepper by Bemisia tabaci (Genn.). J. Entomol. 5:176-184.

Morales, F.J. and P.K. Anderson. 2001. The emergence and dissemination of whitefly-transmitted geminiviruses in Latin America. Arch. Virol. 146:415-441.

Nakhla, M., A. Sorensen, L. Mejía, P. Ramírez, J. Karkashian, and D. Maxwell. 2005. Molecular characterization of tomato-infecting begomoviruses in Central America and development of DNA-based detection methods. Acta Hort. 695:277-288.

Pappu, H.R., R.A.C. Jones, and R.K. Jain. 2009. Global status of tospovirus epidemics in diverse cropping systems: Successes achieved and challenges ahead. Virus Res. 141:219-236.

Pasko, P., R.G. Ortega, and M.L. Arteaga. 1996. Resistance to potato virus $\mathrm{Y}$ in peppers. Capsicum Eggplant Nwsl. 15:11-27.
Pickersgill, B. 1997. Genetic resources and breeding of Capsicum spp. Euphytica 96:129-133.

Rai, V.P., R. Kumar, S.P. Singh, S. Kumar, S. Kumar, M. Singh, and M. Rai. 2014. Monogenic recessive resistance to Pepper leaf curl virus in an interspecific cross of Capsicum. Sci. Hort 172:34-38.

Retes-Manjarrez, J.E., S. Hernández-Verdugo, A. Evrard, and J.A. Garzón-Tiznado. 2017. Heritability of the resistance to Pepper huasteco yellow vein virus in wild genotypes of Capsicum annuum. Euphytica 213:275.

Retes-Manjarrez, J.E., S. Hernández-Verdugo, B. Pariaud, L.A. Hernández-Espinal, S. ParraTerraza, D.L. Trejo-Saavedra, R.F. RiveraBustamante, and J.A. Garzón-Tiznado. 2018. Resistance to Pepper huasteco yellow vein virus and its heritability in wild genotypes of Capsicum annuum. Bot. Sci. 96:1-11.

Retes-Manjarrez, J.E., S. Hernández-Verdugo, B. Pariaud, C.M. Melgoza-Villagómez, A. PachecoOlvera, S. Parra-Terraza, and J.A. GarzónTiznado. 2016. Detección de resistencia al Virus huasteco vena amarilla del chile y su heredabilidad en genotipos silvestres de Capsicum annuum L. Interciencia 41:541-547.

Secretaría de Agricultura, Ganadería, Desarrollo Rural, Pesca y Alimentación, Servicio de Información Agroalimentaria y Pesquera, México. 2018. 6 Nov. 2018. <www.siap.gob.mx>.

Shankarappa, K., S. Sriharsha, K.T. Rangaswamy, D.S. Aswathanarayana, H.A. Prameela, R.S. Kulkarni, V. Muniyappa, A.M. Rao, and M.N. Maruthi. 2008. Development of tomato hybrids resistant to tomato leaf curl virus disease in South India. Euphytica 164:531-539.

Singh, J. and M.R. Thakur. 1977. Genetics of resistance to tobacco mosaic virus, cucumber mosaic virus and leaf curl virus in hot pepper (Capsicum annuum). Proc. $3^{\text {rd }}$ Eucarpia Meeting on Capsicum Working Group, Montfavet, Avignon, France, 5-8 July 1977.

Torres-Pacheco, I., J.A. Garzón-Tiznado, J.K. Brown, A. Becerra-Flora, and R.F. RiveraBustamante. 1996. Detection and distribution of geminiviruses in Mexico and the southern United States. Phytopathology 86:1186-1192.

Trujillo-Aguirre, J. and R. Díaz-Plaza. 1995. Obtención de cultivares de chile habanero con resistencia a virosis transmitida por mosca blanca: IV. Taller latinoamericano sobre moscas blancas y geminivirus. Zamorano, Honduras.

van Zonneveld, M., M. Ramirez, D.E. Williams, M. Petz, S. Meckelmann, T. Avila, C. Bejarano, L. Ríos, C. Peña, M. Jager, D. Libreros, K. Amaya, and X. Scheldeman. 2015. Screening genetic resources of Capsicum peppers in their primary center of diversity in Bolivia and Peru. PLoS One 10:e0134663.

Varma, A. and V.G. Malathi. 2003. Emerging geminivirus problems: A serious threat to crop production. Ann. Appl. Biol. 142:145-164.

Wang, D. and P.W. Bosland. 2006. The genes of Capsicum. HortScience 41:1169-1187.

Yao, M., N. Li, F. Wang, and Z. Ye. 2013. Genetic analysis and identification of QTLs for resistance to cucumber mosaic virus in chilli pepper (Capsicum annuum L.). Euphytica 193:135-145. 